Historic, Archive Document

Do not assume content reflects current scientific knowledge, policies, or practices. 



\title{
GLADIOLUS 11
}

\author{
of \\ MERIT
}

1928

\section{FRANK W. MELICK SPENCER, IND. \\ U. S. A.}





\section{CULTURAL DIRECTIONS}

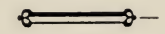

The gladiolus is easy to grow. It will do well in almost any good garden soil, but a rich, sandy loam is best.

Do not plant in the shade of trees or buildings. Especially stay away from trees and shrubs, whose tiny roots suck all the moisture out of the ground in a wide circle.

May be planted from middle of April to latter part of May. Plant in rows, in four or five inch deep trenches, five to six inches between each bulb in the row and at least twenty inches between the rows.

Keep the top soil continually loose and free from weeds. Never allow a hard crust to form after rain or watering. In case of a long severe drought, soak the soil thoroughly once a week at least. Constant cultivation will also help wonderfully.

In cutting the flower spike allow at least four leaves to remain on the stalk. It weakens the bulb to cut stem too low.

Do not plant gladioli in the same patch many years in succession. New ground each year is best. Do not use horse manure as fertilizer. Ground fertilized with old cow manure the previous year is best.

Mark each variety with its proper name, written on a tag, tied to a stake. At blooming time it will add to your pleasure to know the right name of each variety.

Dig bulbs in the late fall and, immediately after digging, cut the stem close to the bulb. Use a sharp krife or a small pruning shear, so you do not tear the husk.

Dry them in open air for a week or two, but protect them from frost at nights. Remove the roots and dirt and the old, decayed bulb. Save the bulblets and plant them again in the spring. Sow them thickly, like peas, in shallow trenches, about two inches deep. They will bloom the second year.

When properly dried and cured store your bulbs away for the winter in a dry, frostproof place in the cellar.

On account of its extraordinary keeping qualities, the gladiolus surpasses all other flowers for cutting purposes. A bouquet can be kept fresh in a vase for a week or more. Not only that, but the blooms will prove even larger, brighter and more beautiful and perfect in every way when cut than when out in the sunny garden.

For the sick-room and hospital and for decorating churches and halls the gladiolus is the ideal flower, not only because of its beauty and stateliness and almost unlimited color-range, but also because of its lack of fragrance. 


\section{IN ORDERING}

Print or write very plainly, your name and address. Proper rames are very hard sometimes to make out.

\section{ORDERS}

Are booked and filled in rotation as received. All orders received subject to prior sale. If sold out on a variety ordered we will not substitute another variety unless requested to do so, however we will, unless notified otherwise, substitute a different size of the same variety, when sold out of size ordered.

At prices quoted we can't make a profit on orders of less than $\$ 2.00$ but if sent in we will fill them, profit or or no profit.

\section{SIZES}

L. (large) is $1 \frac{1}{4}$ inches and up; M. (medium) is from $3 / 4$ inch up to $1 \frac{1 / 4}{4}$ inches; $S$. (small) is $3 / 4$ inch and less. Bulblets are all hand picked and are the largest ones in each respective variety.

\section{TERMS}

Cash, or $25 \%$ down, and balance C. O. D. Prices are postpaid or express paid anywhere in the U. S. or Canada. Shipments made during January and February at purchaser's risk only.

\section{DISCOUNTS}

Instead of issuing both wholesale and retail lists, I am giving suitable discounts on quantity orders, thus eliminating much confusion.

On all cash orders you may select extra bulbs and bulblets as follows; $-5 \%$ extra on orders from $\$ 5.00$ to $\$ 25.00 ; 10 \%$ on $\$ 25.00$ to $\$ 50.00 ; 15 \%$ on $\$ 50.00$ to $\$ 100.00$; $20 \%$ on $\$ 100.00$ or more.

Where bulbs and bulblets are not listed, you may have 6 for the price of 5, 1 for 10 th of doz. rate, 25 at 100 rate, 1000 at 9 times 100 rate, and 250 at 1000 rate.

Prices or larger quantities than quoted herein will be given on varieties requested, by letter. Let us know your wants.

\section{GUARANTEE}

We exercise every precaution to have all stock true to name and free from disease, but if a mistake should occur notify us as soon as found, and tell us what you would like to have done. We are anxious to please you.

\section{REFERENCES}

The Spencer National Bank

The Exchange Bank

Chamber of Commerce

All of Spencer, Indiana. 


\section{YOU ARE WELCOME}

To visit our gardens any time. Greenhouse and gardens are located at East end of the beautiful little city of Spencer; nationally known, not only as a flower city, but also the center of population of the UNITED STATES. Can be reached via Indianapolis and Vincennes division of the Pennsylvania railroad; or state highways No. 67, 43 and 46.

Open for business week days only.

A. E. KUNDERD (Kunderd)-Rich salmon-rose, lighter towards certer of throat with very beautiful markings on three lower petals. Florets large on a tall, strong spike. Very nicely ruffled. (L. \$3.00 ea.) (M. $\$ 2.00$ ea.) (S. $\$ 1.00$ ea.) (Blts. $30 \mathrm{c}$ ea. $\$ 20.00$ per $100)$.

ALBANIA (Kemp)-Pure glistening white, with large wide open flower, correctly placed on spike, and very artistic. Good keeper when cut and one of the best commercial whites in existence. (L. 7c ea. $\$ 5.00$ per 100.) (M. 5c ea. $\$ 3.50$ per 100.) (S. 3c ea. $\$ 1.50$ per 100.) (Blts. 20c per $100, \$ 1.50$ per 1000.$)$

ALLEN V. BUNCE (Bill)-Livid orange yellow with clear central lines of deep claret. Large, well opened winged florets, gracefully placed on long wiry stem. This variety will become more popular when stock is available. (L. 70c ea.) (Blts. 50c per doz. $\$ 2.50$ per 100.)

AMEGLASO (J. C. Davis)-Originator describes this variety as a wonderful creamy white, good texture, strong grower, and many open at once. The name is an abbreviation of American Gladiolus Society. (M. $\$ 10.00$ ea.) (Blts. $\$ 1.00$ ea.)

ANTONIA ANTONETTE (Kunderd)-Soft salmon pink. Very strong tall grower. A good one. (M. 90c ea.) (S. $55 \mathrm{c}$ ea.) (Blts. 10c ea.)

ARABY (Bill)-Medium large flowers of rosaline pink, with tyrian rose throat. Buds chatanay pink; top petal slightly hooded. (L. $\$ 2.00$ ea.) (Blts. 20c ea.)

BALBOA (Briggs)-Clear glowing apricot pink blending into a warm yellow throat. Five to seven large reflex blooms open at one time. Good under artificial light. A good propagator. (L. $\$ 2.00$ ea.) (Blts. 20c ea.)

BARBARA LA MARR (Diener)-A very fine geranium pink. Good substance and a good propagator. (L. $\$ 3.00$ ea.) (Blts $30 \mathrm{c}$ ea.) 
BENGAL TIGER (Pratt)-The name suggests its color. Something different, and a good grower too. (L. 7c; $\$ 5.50$ per 100 .) (M. 5c; $\$ 3.75$ per 100 .) (S. 3c; $\$ 2.00$ per 100.) (Blts. $15 \mathrm{c}$ per $100, \$ 1.25$ per $1,000$.

BERNARD SHAW (Diener)-White shaded lilac, amaryllis shaped bloom. (L. 70c ea.) (M. 50c ea.) S. 30 c ea.) (Blts. 10 for 25 c, $\$ 2.25$ per 100 .)

BETTY JOY (Bill) - Soft creamy white flushed LaFrance pirk. Strong grower, long spikes with many open at a time. Rated $97 \%$ by Gersdorff. (S. 30 ea.) (Blts. 75c per doz.)

BOUQUET FLOWER (Miller)-Large tall spike; very large reflex flowers, white overlaid palest blush, canary tinge in throat. Tips of petals are lightly rayed lilacrose. Many open at a time. Nicely ruffled. (L. \$7.50 ea.) (M. $\$ 5.00$ ea.) (Blts. $\$ 1.00$ ea.)

BREAK O' DAY (Bill)-_-Soft LaFrance pink flushed over a cream ground with the shade deepening at tips of petals. This variety being extra early, many open at a time, well placed on spike and of the finest quality, is a dardy to tie on to. (L. 40c ea. $\$ 28.00$ per 100.) (M. 25c ea $\$ 18.00$ per 100.) (S. 15 c ea. $\$ 10.00$ per 100 .) (Blts. 25c per doz., $\$ 1.75$ per $100, \$ 15.00$ per 1000.)

BUDDY WORDEN (Austin)-Capuchine orange feathered rose doree with slight tinting of rose on tips of petals. Medium size bloom on heavy spikes. (L. 50c ea.) (M. 30c ea.) (Blts. 50c per doz.)

BUTTERBOY (Kunderd)-Large buttercup yellow primulinus. A beautiful basket gladiolus. (L. 10c ea.) (Blts. 10c per doz.)

CANANDAIGUE RED (Bill)-A solid color of red shade slightly lighter than true carmine. Strong grower, large massive spikes, and wonderful individual flowers. A real acquisition to the red class. (L. 55c ea.) (M. 35c ea.) (S. 25c ea.) (Blts. 25c per doz.)

CAPT. BOYNTON (Boynton)-Lavender with maroon blotch. Very tall spike with large well opened flowers. A beauty. (L. 25c ea.) (M. 20c ea.) (S. 15c ea.) (Blts. 25c per doz., $\$ 1.50$ per 100.)

CARA MIA (Miller)-LaFrance pink blushed salmon pink with a creamy salmon sheen. Nicely ruffled, perfectly placed flowers on a tall spike. Early, very prolific and a good cut flower. (L. \$7.50 ea.) (Blts. 75c ea.)

CATALINA (Briggs)-Bright rosy pink with a vivid lemon yellow throat. Six to seven large, well opened flowers of good texture at a time, and a good propagator. (M. $\$ 4.00$ ea.) (S. \$3.00 ea.) (Blts. 50c ea.) 
CARMEN SYLVA (Prestgard)-Pure snow white, throat slightly penciled lilac. Almost self color. Stem tall and slender but wiry. A most excellent cut flower. (L. 6c ea., $\$ 4.50$ per 100 ) (M. 4c ea., $\$ 2.75$ per 100.) (S. $2 c$ ea.. $\$ 1.25$ per 100 .) (Blts. 15c per $100, \$ 1.00$ per 1000.)

CATHERINE COLEMAN (Coleman)-Very large clear salmon rose pink with darker pencilings on lower petals. Many open at a time. A wonderful exhibition variety. (L. 40c ea.) (M. 30c ea.) (S. 20c ea.) (Blts. $35 \mathrm{c}$ per doz., $\$ 2.00$ per 100 .)

CE ME (Christ)-(L. $\$ 3.00$ ea.) (Blts. 30c ea.)

CLEOPATRA (Bill)--Deep bronzy yellow. Large flowers on tall massive spike. Six or more open at a time. A very attractive late variety. (L. 75c ea.) (M. 50c ea.) (S. 25c ea.) (Blts. 40c per doz., \$3.50 per 100.)

COPPER BRONZE (Kunderd)--The color suggests the name. Very striking as a vase flower. (M. 40c ea.) (S. 30c ea.) (Blts. 75c per doz.)

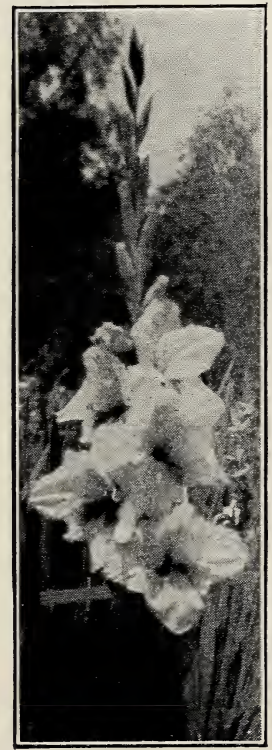

CORONADO

(Briggs)

CORONADO (Briggs)-One of the very finest in existence today. A very large heavily ruffled white with a royal purple blotch in the throat. This variety has been increasing instead of decreasing in price. (L. $\$ 25.00$ ea.) (M. $\$ 20.00$ ea.) (S. $\$ 15.00$ ea.) (Blts. $\$ 5.00$ ea.) 
CREATORE (Bill)-One of Bill's best. Rose doree with a throat line of carmine red. Tall, strong spikes with very large flowers. A good propagator. (L. $\$ 10.00$ ea.) (S. $\$ 5.00$ ea.) (Blts. $\$ 1.00$ ea.)

CROWN OF GOLD (Biil)-Pure straw yellow, tall spike, large flowers, placed in single row. (L. \$2.00 ea.) (M. $\$ 1.50$ ea.) (S. $\$ 1.00$ ea.) (Blts. 20c ea.)

D. AMERICAN BEAUTY (Diener)-American Beauty rose color with creamy yellow throat. The best in its color. A dwarf grower but has a whole spike full of flowers open at a time. (L. $10 \mathrm{c}$ ea., $\$ 7.00$ per 100.) (M. 7c ea., $\$ 5.00$ per 100) (S. 4c ea., $\$ 3.00$ per 100.) (Blts. 25c per $100, \$ 1.25$ per 1000.)

DAY DREAM (Christ) -(L. $\$ 3.00$ ea.) (Blts. 30c ea.)

DREADNAUGHT (Miller)-Enormous flowers, perfect placement. Pure salmon large cream spots on lower petals. Finely waved and ruffled. (M. \$15.00 ea.)

DR. F. E. BENNETT (Diener)-Deep peach red overlaid with flame scarlet. Lip speckled ruby and white. Known as the "House Afire Red". One of the very best in its color. (L. 30c ea.) (M. 20c ea.) (S. 10c ea.) (Blts. 20c per doz. $\$ 1.00$ per $100, \$ 8.00$ per 1000 .)

DR. NELSON SHOOK (Kunderd)-Deep tyrian rose. A giant spike and flower. Has won many prizes. (S. 40c ea.)

DR. W. VAN FLEET (Kunderd)--Extra tall slender spike Flowers of good form and size. Delicate rose pink, deeper at edges, with throat of softest canary yellow. Very early. (L. 5c ea., \$3.50 per 100.) (M. 3c ea., $\$ 1.75$ per 100) (S. 2c ea., 75c per 100.) (Blts. 10c per 100, 75c per 1000.)

EARLY SUNRISE (Velthuys)-A very early salmon. Flowers large and well placed on a strong spike. (L. 10c ea.) (Blts. 10c per doz.)

ELDORA (Kemp)-Capucine buff, shading to grenadine pink, flaked jasper red. The lower petal has a very narrow stripe of amaranth purple. The beauty of this one must be seen to be appreciated. Large flowers four to five open at once on tall spikes. (L. $75 \mathrm{c}$ ea.) (M. 55c ea.) (S. 35c ea.) (Blts. $75 \mathrm{c}$ per doz.)

ELF (Diener)-Buds lemon yellow, flowers pure white, lip delicate lemon. Large flowers on a perfectly built spike. Very prolific and a commercial variety of promise. (L. 5c ea., $\$ 3.50$ per 100.) (M .3c ea., $\$ 1.75$ per 100.) (S. 2c ea., $75 \mathrm{c}$ per 100.) (Blts. 10c per 100, 60c per 1000.) 
ELIZABETH SWARTLEY (Swartley)-A lighter shade of 1910 ROSE with almost white throat. Has 1910 ROSE habits and should prove to be a comer in the commercial field. (L. $\$ 1.00$ ea.) (M. 75c ea.) (Blts. 10 c ea.)

ELIZABETH TABOR (Hinkle)-Pink with carmine blotch, very early and a choice variety. (L. 10c ea.) (M. 6c ea.) (S. 3c ea.) (Blts. 25c per 100, $\$ 2.00$ per 1000.)

EMILE AUBURN (Lemoine)-Coppery bronze with cherry blotch. Extra large bloom, and a strong grower. Very distinct and unusual. You will like it. (M. 75c ea.) (S. 50c ea.) (Blts. $75 \mathrm{c}$ per doz.)

EVELYN KIRTLAND (Austin)-A large open flower, with rose pink center and brilliant scarlet blotch on lower petals. Tall grower and a very good cut flower variety. (L. 5c ea.) (M. 3c ea.) (S. 2c ea.) (Blts. 10c per $100,75 \mathrm{c}$ per 1000 .)

FASTIDIOUS (Bill)-Very large open flowers of delicate shell pink, shading to ivory white at the throat. A late bloomer. (L. 25c ea.) (M. 15c ea.) (S. 10c ea.) (Blts. 25c per doz., $\$ 2.00$ per 100.)

FAY LANPHIER (Williams)-Coral luster with cerise blending. A most beautiful flower on a graceful spike. Large open flowers lasting well when cut. (L. 25c ea.) (Blts. 25c per doz.)

FERN KYLE (Kunderd)-Large, ruffled creamy white. Very vigorous. (L. 15c ea.) (M. 12c ea.) (S. 8c ea.) (Blts. $60 \mathrm{c}$ per $100, \$ 5.00$ per 1000. )

FLAMBEAU (Miller)-Brilliant salmon orange, overlaid flaming vermillion. Large velvety flowers. Very gorgeous. (M. $\$ 2.00$ ea.) (S. $\$ 1.00$ ea.) (Blts. $25 \mathrm{c}$ ea.)

FLEETWOOD (Bill)-Light geranium pink with five to seven open at once. Almost pure self color. Will be good for commercial use when plentiful. (L. $\$ 3.00$ ea.) (Blts. 30c ea.)

FONTAINE (Coleman)-Dainty ruffled peaches and cream color. You will like it. (M. 8c ea.) (S. 6c ea.) (Blts. 10c per doz.)

FORT SUMNER (Bill)-Pure self scarlet red. Very large wide open flower with all petals nearly equal in size. Many open at a time. (M. $\$ 5.00$ ea.)

GENESEE (J. C. Davis)-Said by some to be one of the three best commercial varieties for 1930 , when stock should be plentiful. Large pale yellow Primulinus Grandiflorus, strong vigorous grower and always erest. Placement and florescence very good. (L. 20c ea.) (M. 15c ea.) (S. 10c ea.) (Blts. 25c per doz., $\$ 1.75$ per $100, \$ 15.00$ per 1000 .) 
GEORGE J. JOERG (Joerg) - A wonder in size and color. Buds are intense carmine scarlet, toning out as they develop into a beautiful rich salmon pink. Each petal has a distinctly blanched central rib, the lower petal being especially beautiful. (L. $\$ 3.50$ ea.) (Blts. 35c ea.)

GERALDINE FARRAR (Diener)-Pale lavender violet with deep violet spot on lip. Strong grower and in good demand. (L. $\$ 1.25$ ea.) (M. $\$ 1.00$ ea.) (S. 60c ea.) (Blts. $15 \mathrm{c}$ ea., $\$ 10.00$ per 100 .)

GERTRUDE ERREY (Errey)-An exquisite shade of shell pink on the outer part of flower, shading to almost white in center, with a spot of deeper color in throat. Large flowers, graceful in form and well placed on tall spikes. (L. 50c ea.) (M. 35c ea.) (S. 20c ea.) (Blts. 50c per doz., $\$ 3.00$ per 100.)

GIANT NYMPH (Coleman)-LaFrance pink with creamy yellow throat. Large wide open flowers and well arranged on the spike. Very popular and justly so. (L. 20c ea.) (M. 15c ea.) (S. 10c ea.) (Blts. 60c per 100.)

GLADDIE BOY (Bill)-Color very distinctive, the general effect being a grenadine pink gradually blending into straw yellow deep in the center. (L. 90c ea.) (M. 65c ea.) (S. 40c ea.) (Blts. 90c per doz.)

GLORIANA (Betscher)--Rich salmon with creamy throat. Many flowers open at a time. (M. 55c ea.,) (S. 35c ea.) (Blts. 40c per doz.)

GOLD (Hoeg) - Pure golden yellow, throat a shade deeper, slightly dotted and streaked. Large flowers, perfect placement. A good cut flower. (L. 8c ea.) (M. 5c ea.) (S. 3c ea.) (Blts. 20c per 100, $\$ 1.50$ per 1000.)

GOLDEN EAGLE (Austin)-A coming leader in the yellow class. Blooms good size and a deep, rich, pure yellow. Petals of good substance, nicely ruffled and very resistent to heat. Extra early, prolific and in every way a tribute to Mrs. Austin's skill. (L. \$3.00 ea.) (M. $\$ 1.90$ ea.) (S. $\$ 1.40$ ea.) (Blts. $40 \mathrm{c}$ ea., $\$ 3.50$ per doz., $\$ 27.00$ per 100.)

GOLDEN DREAM (Groff)-Another fine, clear, deep yellow that you will want. Has won many prizes and will be very popular when stock is more plentiful. (L. $\$ 3.00$ ea.) (M. $\$ 2.00$ ea.) (S. $\$ 1.00$ ea.) (Blts. 35c ea.)

GOLDEN FRILLS (Kunderd)-A primulinus hybrid of superior quality. Large open flowers of deep, rich daffodil yellow with pink lines on lower petals. Intensely ruffled and very choice. (L. $\$ 2.75$ ea.) (M. $\$ 1.60$ ea.) (S. $\$ 1.10$ ea.) (Blts. $15 \mathrm{c}$ ea., $\$ 12.00$ per 100.) 
GOLDEN MEASURE (Kelway) - The old standby. Widely used as a seed parent. Large, fine yellow, self color, on a massive, well formed spike. (L. 7c ea.) (M. 5c ea.) (S. 3c ea.) (Blts. 20c per $100, \$ 1.50$ per 1000.)

GOLDEN SALMON (Kunderd)-A very good ruffled gladiolus of beautiful golden yellow and pink shades artistically blended. (M. 55c ea.) (S. 35c ea.) (Blts. 10 c ea.)

GOLDEN SWALLOW (Austin)-Clear yellow free from markings, and so beautiful and artistic in form as to resemble a flying bird. (L. 15c ea.) (M. 10c ea.) (S. 5c ea.) (Blts. 30c per $100, \$ 2.50$ per 1000 .)

HALCYON (Bill)-A strong grower, straight and extra long flower head on tall spike. Color a soft rose pink shading deeper toward petal tips. (L. \$1.25 ea.) (M. $80 \mathrm{c}$ ea.) (S. $40 \mathrm{c}$ ea.) (Blts. $75 \mathrm{c}$ per doz.)

HALO (Miller)-Golden orange overlaid golden salmon and peach. Very brilliant color, good spike and a fair sized flower. (L. $\$ 3.00$ ea.) (M. $\$ 2.00$ ea.) (S. $\$ 1.00$ ea.) (Blts. 25c ea.)

HARBINGER (Sanford)_Grenadine red, blended and shaded Mars orange on tips and edges, bases of lower petals salmon orange with deeper feather blotch. Primulinus grandiflorus type, prolific and a variety you will want in your collection. (L. $\$ 3.00$ ea.) (M. \$2.00 ea.) (S. $\$ 1.00$ ea.) (Blts. 25 e ea., $\$ 20.00$ per 100 .)

HEAVENLY BLUE (Holland)-A splendid novelty. Wonderful, pleasing, soft blue color. Sort of a heliotropelilac. Very long spike with many flowers open. (M. $\$ 8.00$ ea.) (S. $\$ 5.00$ ea.) (Blts. $\$ 1.00$ ea.)

HELEN HOWARD (Austin)-General color buff flushed coral with dainty dashes of peach red, and throat of purest amber. Blooms wide open and daintily frilled. Tall spike and many open at a time. (L. 75c ea.) (M. 50c ea.) (S. 35c ea.) (Blts. 75c per doz., $\$ 5.00$ per 100.)

HELEN PHIPPS (Phipps)-Deeper and brighter than Mr. W. H. Phipps, Very strong grower with ten or more large blooms open at a time. A magnificient variety. (L. $\$ 5.00$ ea.) (M. \$3.50 ea.) (S. \$2.00 ea.) (Blts. 50c ea.)

HELEN WILLS (Salbach)-Another good white of recent introduction, worthy of a place in your collection. (L. $\$ 1.75$ ea.) (M. $\$ 1.00$ ea.) (S. 50c ea.) (Blts. 15c ea.)

HENRY FORD (Diener) - A very dark rhodamine purple. Flowers usually point opposite on spike, but the color makes up for its lack in form. (L. 10c ea., $\$ 7.00$ per 100.) (M. 5c ea., $\$ 3.50$ per 100.) (S. 3c ea., $\$ 1.50$ per 100.) (Blts. 20c per $100, \$ 1.50$ per 1000.$)$ 


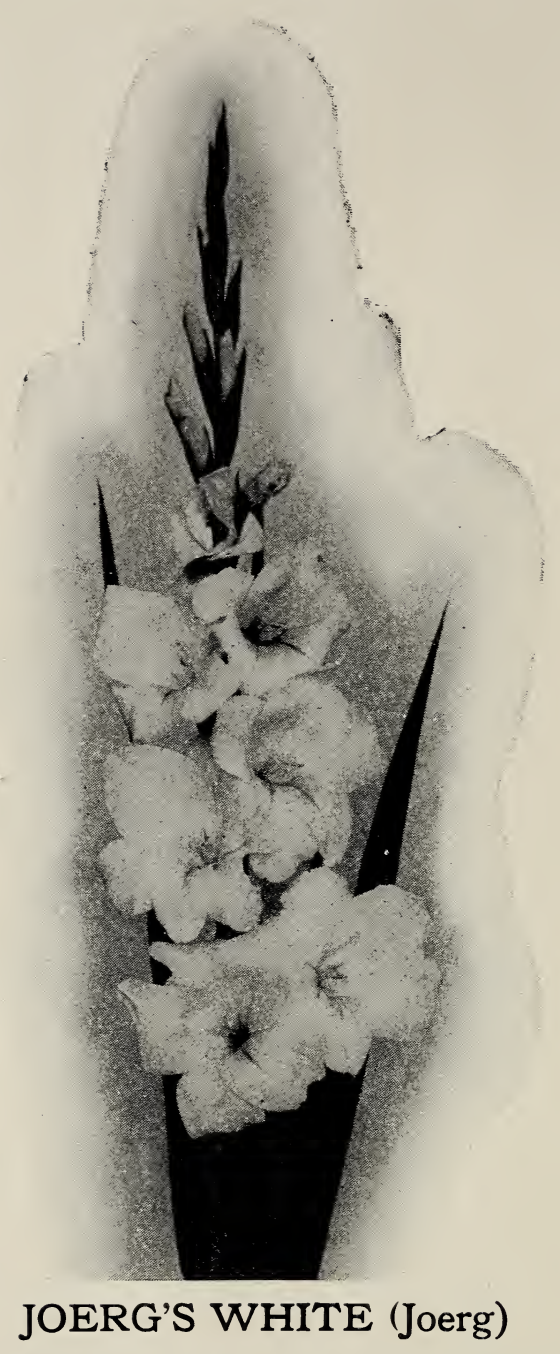

JOERG'S WHITE (Joerg)-The largest pure white I know of. Five petals usually show no other color. Lower petal shades to creamy white with crimson veinings. (L. 90c ea.) (M. 50c ea.) (S. 30c ea.) (Blts. 85 c per doz., $\$ 5.00$ per 100 .) 
IDAMAE (Salbach) - Very large wide open ivory white. Lower petals overlaid pinard yellow with delicate rose pencilings and throat markings. (L. 10c ea. (M. $8 \mathrm{c}$ ea.) (S. 5c ea.) (Blts. 10c per doz.)

J. A. CARBONE (Diener)-Iridescent orange-salmon, shading darker towards edge of petals. Yellow center. A very attractive variety. (L. 10c ea.) (M. 6c ea.) (S. 3c ea.) (Blts. 15c per $100, \$ 1.25$ per 1000.)

JACOB VAN BEIREN (Hemmskerk)-Violet. Extra large bloom on tall spike. Many open at once. One of the near blues. (L. 15c ea.) (M. 10c ea.) (S. 5c ea.) (Blts. 30c per 100.)

JENNY LIND (Hoeg)-Pure soft apricot pink, throat pale yellow, the two colors blending to perfection. An exceedingly refined and attractive variety. (L. 10c ea.) (M. 7c ea.) (S. 4c ea.) (Blts. 55c per 100, $\$ 4.50$ per 1000.)

JOE COLEMAN (Kunderd)-Rich red, very large and vigorous. A good propagator, and is very popular. (L. 7c ea.) (M. 5c ea.) (S. 3c ea.) (Blts. 15c per 100.)

JOERG'S WHITE PRIM. (Joerg)-Pure white primulinus grandiflorus with pale yellow throat. A mighty fine basket glad. (L. $\$ 1.00$ ea.) (M. 75c ea.) (S. 50c ea.) (Blts. 85c per doz., $\$ 5.00$ per 100.)

JOERG'S YELLOW PRIM. (Joerg)-An improvement in the yellow primulinus class. Large pure yellow with a faint crimson midrib on the lower petal. Prices same as Joerg's White Prim.)

JOSEPH FIELD (Diener)-Dawn pink slightly striped with mallow pink and ruby. Lip has stripe of creamy white. Extra large flowers on long, well built spike. Fine for exhibition. (M. 75c ea.) (S. 50c ea.) (Blts. $\$ 1.00$ per doz.)

JUBILEE (Kemp)-A masterpiece in the gladiolus world. Enormous size, perfect placement and in color a light vinaceous lavender. One of the best in existence and will be very high in price for several years. (L. $\$ 90.00$ ea.) (Blts. $\$ 10.00$ ea.)

KING TUT (J. C. Davis)-A real novelty. Basic color begonia rose but contains about all the colors known to ancient Egyptians. Colors are blended nicely, flowers very large and many open at once. (L. \$15.00 ea.) (M. $\$ 10.00$ ea.) (S. $\$ 5.00$ ea.) (Blts. $\$ 1.00$ ea.)

LACINATUS (Kunderd)-Introduced at $\$ 1,000.00$ per bulb. Small rose pink with edge of petals cut or lacinated. Valuable chiefly as a seed parent. (M. $20 \mathrm{c}$ ea.) (S. 10c ea.) (Blts. 35c per doz., $\$ 2.00$ per 100.) 
JUNIATA (Kemp)-The very essence of charm and beauty. Very light pink, the three lower petals creamy white shading to LaFrance pink and flaked with begonia rose. A harmonious blending of dainty colors hard to describe. (L. $\$ 2.40$ ea.) (M. $\$ 1.90$ ea.) (S. $\$ 1.40$ ea.) (Blts. 25c ea.)

LA COURONNE (Lemoine)-Creamy white with red blotch on lower petals. Large, well formed flowers and many open at a time. (L. 12c ea.) (M. 8c ea.) (S. 5c ea.) (Blts. 10c per doz.)

LADY BYNG (Gilchrist)--Shell pink of delicate, refined appearance. Vigorous grower and very early. Five to six flowers open at a time. (M. 25c ea.) (S. 15c ea.) (Blts. 35e per doz.)

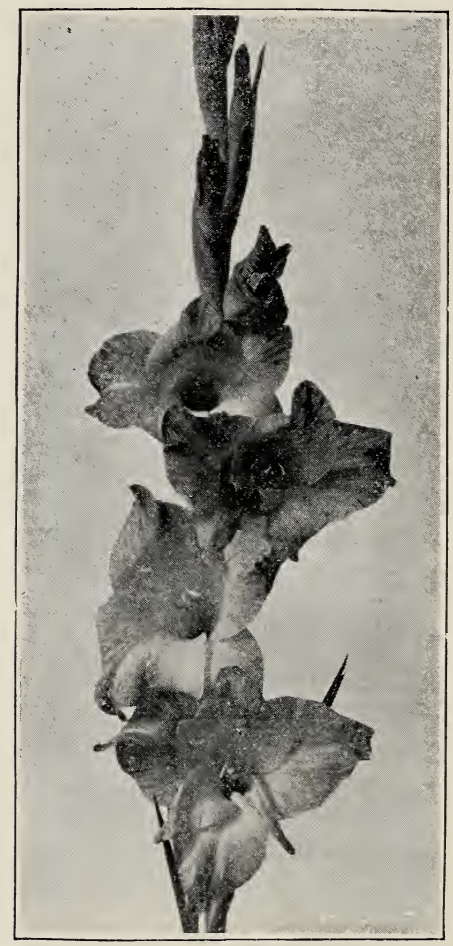

JUNIATA (Kemp) . 
I.AVENDER PRINCESS (Williams)-Very light lavender. Large flowers, many open at once on medium tall spikes. (L. 20c ea.) (M. 15c ea.) (S. 10c ea.) (Blts. 20c per doz.)

LE MARECHAL FOCH (Van Deursen)-Cameo pink. Very early and prolific. Grown by the acre for the florists trade. (L. 4c ea., $\$ 1.75$ per 100) (M. 2c ea., $\$ 1.00$ per 100 ) (S. 1c ea., 50c per 100) (Blts. 10c per $100,50 \mathrm{c}$ per 1000 .)

LILLIAN GISH (Diener) - White with yellow markings on lower lip. Tall spike and many flowers open at a time. (L. $\$ 4.00$ ea.) (M. $\$ 3.00$ ea.) (Blts. $40 \mathrm{c}$ ea.)

LONGFELLOW (Prestgard)--LaFrance pink. One of the best in its class. A variety in great demand. (L. 60c ea.) (M. 40c ea.) (S. 25c ea.) (Blts. 35c per doz., \$2.25 per 100.)

LOS ANGELES (Houdyshel) - The so much talked of cut-and-come again glad. As near an ever bloomer as has so far been achieved in gladiolus breeding. A delicate pink with cerise throat feather. (L. 15c ea.) (M. 10c ea.) (S. 5c ea.) (Blts. 35c per $100, \$ 3.00$ per 1000.)

LOUIS HEMON (Lemoine)-Three inner petals pure yellow, outer petals salmon striped orange red. Plant of medium height. A very odd novelty. (M. 25c ea.) (S. 15c ea.) (Blts. 35c per doz.)

LUTHER BURBANK (Kunderd)--Deep geranium red, border of petals has delicate bluish line. Throat blended lighter. Lower petals feathered deep red. Ruffled, large blooms and many open at a time. (L. $\$ 20.00$ ea.) (M. $\$ 10.00$ ea.) (Blts. $\$ 2.00$ ea.)

MARIE KUNIEERD (Kunderd)---One of the best early whites for cut flowers. Large bloom, ruffled and in every way a very satisfactory variety. (L. 8c ea., $\$ 6.75$ per 100.) (M. $5 \mathrm{c}$ ea., $\$ 4.00$ per 100 .) (S. 3c ea., $\$ 2.00$ per 100.) (Blts. 25c per $100, \$ 2.25$ per 1000 .)

MARINA (Kemp) Geradine orange with Tyrian rose feathering. A strong grower and very prolific. (L. 20c ea.) (M. 15c ea.) ( S. 10c ea.) (Blts. 20c per doz.)

MARY FREY (Gelser)-One of the few very finest in existence. Beautiful lavender-pink with ruby blotch on lower petal; resembles a cattleya orchid in color and as beautiful. Flowers are of large size perfectly placed, and with 6 to 9 open at once. Extra early, vigorous grower and very prolific. (L. $\$ 15.00$ ea.) (M. $\$ 10.00$ ea.) (S. $\$ 7.50$ ea.) (Blts. $\$ 3.00$ ea., $\$ 25.00$ per doz.) 
MARY JANE (Kunderd) - Silvery pink with light lavender sheen. Named in honor of the originator's mother. (M. $\$ 2.50$ ea.) (S. $\$ 1.50$ ea.) (Blts. 30c ea.)

MARY O' MINE (Bales)-One of Mrs. Austin's originations, brought and introduced by Dr. Bales. A pure crystal white except for faint violet markings down deep in the throat. Tall, slender, graceful spikes, with several large blooms open at a time. (M. \$5.00 ea.) (S. $\$ 2.50$ ea.) (Blts. $50 \mathrm{c}$ ea.)

MARY PICKFORD (Kunderd)-Delicate ivory white with soft sulphur yellow throat. (L. 6c ea., \$5.50 per 100) (M. 4c ea., $\$ 3.50$ per 100.) (S. $2 c$ ea., $\$ 1.50$ per 100.) (Blts. 10c per $100,75 \mathrm{c}$ per 1000.)

MEM. WM. PFITZER (Pfitzer)-Extra early, large pure white. Strong grower and fine spike. (L. 75c ea.) (M. 50c ea.) (S. 30c ea.) (Blts. 75c per doz.)

MERCED (Briggs) - Brilliant orange saffron, shading into a lighter yellow in the throat. Large ruffled bloom and slightly hooded. (L. \$5.00 ea.) (S. \$1.50 ea.) (Blts. 50c ea.)

MING TOY (Kunderd)-Very fine deep buff yellow. One of my favorite basket glads. (L. 6c ea., \$4.75 per 100.) (M. 4c ea., $\$ 3.00$ per 1000.) (S. 2c ea., $\$ 1.25$ per 100.) (Blts. 10c per $100,75 \mathrm{c}$ per 1000 .)

MINUET (Coleman)-Large, clear, delicate, lavender. The best in its class. (L. $\$ 3.00$ ea.) (M. \$2.00 ea.) (S. $\$ 1.00$ ea.) (Blts. 25 c ea., $\$ 20.00$ per 100.)

MIRACLE (Berg)-Delicate blush and soft yellow. Another new one. (L. $\$ 10.00$ ea.) (M. $\$ 7.50$ ea.) (S. $\$ 5.00$ ea.) (Blts. $\$ 1.00$ ea.)

MISS DEMURE (Austin)-White with tips of petals tinted LaFrance pink. Throat is plumed with eosine pink. A very delicate and beautiful color combination. Medium sized blooms on tall graceful spikes. (L. 40c ea.) (Blts. 40c per doz.)

MISSION BELLS (Briggs)-A beautiful hooded primulinus of rich orange pink. Tall graceful spikes and very good for basket work. (L. $\$ 5.00$ ea.) (M. $\$ 3.50$ ea.) (S. $\$ 2.00$ ea.) (Blts. 50 c ea.)

MISS MADISON (Boynton)-Large, clear, delicate pink. (L. 30c ea.) (M. 20c ea.) (S. 10c ea.) (Blts. 15c per doz., 85c per 100.)

MME. SCHUMANN-HEINK (Diener)-Mauvette. A beautiful flower but hard to describe. (M. \$3.00 ea.) (S. $\$ 2.00$ ea.) (Blts. 40c ea.)

MONA LISA (Kunderd)-Very palest rose pink or blushed white. Almost pure self color. (L. 5c ea.) (M. 3c ea.) (S. 2c ea.) (Blts. 15c per 100.) 
MRS. CALVIN COOLIDGE (Kunderd)-A superb grandiflora primulinus. Color salmon rose pink, lower petals soft creamy yellow tint bordered by salmon rose pink. (L. $\$ 11.00$ ea.) (M. $\$ 8.00$ ea.) (Blts. $\$ 1.50$ ea.)

MRS. C. R. HINKLE (J. C. Davis)-Large flower of deep velvet maroon red, with black stripes appearing as though burned in the petals. Is a strong, vigorous grower and good multiplier. (M. \$1.50 ea.) (S. $\$ 1.00$ ea.) (Blts. 20c ea.)

MRS. DR. NORTON (Kunderd)-Fine pink and cream in a wonderful blending of colors. Known as the peaches and cream colored glad. Very popular with the florists. (L. 5c ea.) (M. 3c ea.) (Blts. 15c per 100.)

MRS. F. C. HORNBERGER (Hornberger)-A beautiful pure white without markings. Tall grower, with many large blossoms open at a time. (L. $\$ 2.50$ ea.) (M. \$1.75 ea.) (S. $\$ 1.25$ ea.) (Blts. 25c ea.)

MRS. F. C. PETERS (Fischer)-Fine lavender pink. You will not go wrong in buying this one for cut flowers. (L. 10c ea.) (M. 6c ea.) (S. 4c ea.) (Blts. 30c per 100.)

MRS. FRANK PENDLETON (Kunderd)-Deep rose pink shading to pale pink throat with brilliant red blotch on lower petals. In great demand as a cut flower. (L. 5c ea., \$2.50 per 100) (M. 3c ea., $\$ 1.50$ per 100.) (S. 2c ea., $\$ 1.00$ per 100.) (Blts. $10 \mathrm{c}$ per $100,50 \mathrm{c}$ per 1000.)

MRS. H. E. BOTHIN (Diener)-Light geranium pink, heavily ruffled, scarlet center. Strong spike, good well open flower, and good propagator. A very fine late commercial variety. (L. 5c ea., $\$ 3.50$ per 100 .) (M. 3c ea., $\$ 1.75$ per 100 ) (S. 2c ea., $\$ 1.00$ per 100.) (Blts. $10 \mathrm{c}$ per $100,75 \mathrm{c}$ per 1000 .)

MRS. J. K. ARMSBY (Diener)-Coral pink, delicately penciled with vermillion near edges. Cream throat flaked with ruby. Very large flowers, many open at once, and a good cut flower. (L. 10c ea.) (M. 7c ea.) (S. 5c ea.) (Blts. 15c per $100, \$ 1.25$ per 1000.)

MRS. KR. PRESTGARD (Prestgard)-Pure snow white with faint flesh markings down deep in throat. A good one. (L. 70c ea.) (M. 50c ea.) (S. 30c ea.) (Blts. 70c per doz.)

MRS. LEON DOUGLAS (Diener)-Ground color begonia rose, striped with flame and brilliant scarlet. Lip pale yellow, speckled with ruby. Extra large flowers well set on tall, strong spike. Another mighty fine exhibition variety. (L. 10c ea.) (M. 7c ea.) (S. 4c ea.) (Blts. 30c per 100, $\$ 2.00$ per 1000.)

MRS. M. J. KILLION (Fischer)-A very rare creamy white. (L. $\$ 2.00$ ea.) (M. $\$ 1.25$ ea.) (S. 75c ea.) (Blts. 20 c ea., $\$ 15.00$ per 100 .) 
MRS. P. W. SISSON (Coleman)-A beautiful clear cameo pink. Tall, strong spike, very large flower, and many open at a time. Winner of the Sisson $\$ 100.00$ cash prize. (L. $\$ 2.50$ ea.) (M. $\$ 1.50$ ea.) (S. 75c ea.) (Blts. 25 c ea.)

MRS. TOM RATTRAY (Errey)-Champion of the rose pinks. Has been shown with 19 blooms open at a time. (M. \$2.50 ea.)

MRS. VAN KONYNENBURG (Pfitzer)-Analine blue. Tall spike, large blooms. Very scarce and much sought after. (M. $\$ 2.50$ ea.) (S. $\$ 1.50$ ea.) (Blts. $40 \mathrm{c}$ ea.)

MRS. WM. E. CLARK (Fischer)-Very fine light salmon pirk with bright crimson blotch. Good propagator and very popular. (L. $\$ 1.00$ ea.)

MR. W. H. PHIPPS (Diener)-LaFrance pink overlaid with light salmon rose, lighter towards center. Lower petals slightly flaked ruby. Enormous flowers and a dozen or more open at once. A real masterpiece. (L. 40c ea.) (M. 25c ea.) (S. 15c ea.) (Blts. 80c per $100, \$ 7.00$ per 1,000 .)

MYRA (Kunderd)-Large primulinus. Deep salmon pink over yellow ground. Throat yellow with pink lines. Very showy. (L. 5c ea.) (M. 3c ea.) (S. 1c ea.) (Blts. $10 \mathrm{c}$ per $100,50 \mathrm{c}$ per 1000 .)

1910 ROSE (Kunderd)-Rose pink shading to rose red; buds rose red. Lower petals slightly marked rose red in throat with white center line. A fine, extra early, cut flower variety. (L. 5c ea., \$2.50 per 100) (M. 3c ea., $\$ 1.50$ per 100 ) (S. 2c ea., $\$ 1.00$ per 100.) (Blts. 10 per $100,50 \mathrm{c}$ per 1000 .)

NORMA TALMADGE (Hoeg)-Clear sulphur yellow. Large blooms and many open at a time. Practically all buds show color at same time. (L. 50c ea.) (M. 35 c ea.) (S. 25c ea.) (Blts. 50c per doz.)

NYSIS (Christ)-(L. $\$ 3.00$ ea.) (M. $\$ 2.00$ ea.) (S. $\$ 1.00$ ea.) (Blts. 30c ea.)

OH BOY (Bill)-That expresses ones feeling on seeing it. A brilliant red self color without markings. Very large flowers and one that will attract attention wherever shown. (L. $\$ 10.00$ ea.) (M. $\$ 7.50$ ea.) (S. $\$ 5.00$ ea.) (Blts. $\$ 1.00$ ea.)

OPALESCENT (Bill)-Very large, pale rose lavender. Vigorous and one that is sure to please. (L. 20c ea.) (II. 15c ea.) (S. 10c ea.) (Blts. 60c per 100, $\$ 5.00$ per 1000.) 
ORANGE GLORY (Kunderd)-Large ruffled orange. Very strong grower, but sometimes a shy bloomer. In good demand. (L. 10c ea.) (M. 8c ea.) (S. 5c ea.) (Blts. 15c per $100, \$ 1.25$ per 1000.)

ORANGE WONDER (Kemp)-Very large rich orange. Practically a solid color. One of the very good ones. (L. $\$ 3.50$ ea.) (Blts. 35c ea.)

ORCHID LADY (Spenger)-A beautiful clear orchid lavender with silvery sheen with slight touch of cream in the throat. Vigorous, tall, early and prolific. (L. $\$ 7.50$ ea.) (Blts. $80 \mathrm{c}$ ea.)

PATRIA CARTER (Kunderd)-A premulinus grandiflora that is destined to become very popular when stock is plentiful. Flowers are a beautiful tone of softest, light, shrimp pink with no markings. Tall grower and five to six open at a time. (M. \$3.00 ea.) (S. $\$ 2.00$ ea.) (Blts. $45 \mathrm{c}$ ea.)

PAULINE BELKNAP (Miller)-Very large glowing salmon-orange with a golden saffron sheen. (L. \$3.00 ea.) (S. $\$ 2.00$ ea.) (Blts. 30c ea.)

PAULINE KUNDRED (Kundred)-Pure rose-pink with throat of finest cream, blended perfectly. (S. \$5.00 ea.)

PAUL PFITZER (Pfitzer)-Glowing violet purple. Large blooms and a tall, strong grower. (M. 75c ea.) (S. 50c ea.) (Blts. $\$ 1.00$ per doz.)

PEARL OF CALIFORNIA (Kingsley)-Soft LaFrance pink. Here is a variety that is well worth propagating to the limit. A most wonderful glad with a great future. (L. \$5.00 ea.) (M. \$3.50 ea.) (S. \$2.50 ea.) (Blts. 50c ea.)

PERFECT BEAUTY (Miller)-LaFrance pink, heavily brushed deep rose, purple tongue. Large well opened flowers. (M. $\$ 2.00$ ea.) (S. $\$ 1.00$ ea.) (Blts. 30c ea.)

PFITZERS TRIUMPH (Pfitzer)-Very large salmonorange with small velvet red blotch. A really worth while glad. (M. $\$ 3.00$ ea.) (S. $\$ 2.00$ ea.) (Blts. 40c ea.)

PHAENOMEN (Pfitzer)--Soft salmon rose blending to creamy throat. Large blooms, very attractive and early. (M. 50c ea.) (Blts. 75c per doz.)

PINK WONDER (Kemp)-Soft LaFrance pink flaked geranium pink. Chartreuse yellow in the throat, overlaid with rose feathering. Very large bloom, a strong grower and good propagator. (L. 6c ea.) (M. 4c ea.) (S. 2c ea.) (Blts. 10c per 100,75 c per 1000.)

POLA NEGRI (Diener)-Apricot with yellow lip, shading to old rose and salmon on outer edges. A lovely glad. (L. 6c ea.) (M. 4c ea.) (S. 2c ea.) (Blts. 15c per $100, \$ 1.00$ per 1000.) 
PRIDE OF PORTLAND (Ellis)-Begonia rose. Very attractive. (L. $\$ 9.50$ ea.) (Blts. 75 c ea.)

PRIDE OF WANAKAH (Chriswell)-Rich lavender-rose, deeper in throat. Tall and strong; a very large flower and several open at once. (L. 50c ea.) (M. 35 c ea.) (S. 25c ea.) (Blts. 50c per doz.)

PRINCELY (Kemp)-Very light pink, almost white. Large wide open flowers well placed on a tall, graceful spike. (L. 35c ea.) (M. 25c ea.) (S. 15c ea.) (Blts. $\$ 1.50$ per $100, \$ 12.00$ per 1000 .)

PROF. JAMES TROOP (Grossman)-Eocene pink, flamed scarlet on outer half of petals, bases of lower petals with feather blotch and lines of rose red. Very strong grower. (L. $\$ 1.00$ ea.) (M. 50c ea.) (S. 25c ea.) (Blts. $\$ 1.00$ per doz.)

PUREST OF ALL (Pfitzer)-Large pure white, with many flowers open at a time. (M. 50c ea.) (S. 25c ea.) (Blts. 60c per doz.)

PURPLE BUTTERFLY (Grossman)-Aster purple, lower petals blotched velvety bordeaux. A bybrid prim. (M. 25c ea.) (S. 15c ea.) (Blts. 35c per doz.)

PURPLE GLORY (Kunderd)-Very large ruffled maroon. A shy propagator but one of the showiest in my list. (L. 8c ea., $\$ 7.00$ per 100.) (M. 6c ea., $\$ 5.00$ per 100.) (S. 3c ea., $\$ 2.25$ per 100.) (Blts. 30c per 100, $\$ 2.25$ per 1000.)

QUEEN OF ORANGE (Kunderd)-Orange flaked pale yellow, large flowers. (L. $\$ 2.50$ ea.) (Blts. 25c ea.)

RADIO (Diener)-Rhodonite pink. A very pretty one and one you will want when you see it. (L. $\$ 3.00$ ea.) (M. $\$ 2.00$ ea.) (S. $\$ 1.00$ ea.) (Blts. 30c ea.)

RED TORNADO (Ellis)-The very best velvety red. Not affected by hot sun. You can't go wrong in buying this one. (L. $\$ 19.00$ ea.) (M. $\$ 12.00$ ea.) (Blts. $\$ 1.50$ ea.)

RICHARD DIENER (Diener)-Pure geranium pink with a slight sprinkling of ruby on a creamy yellow center. The acme of perfection in coloring. Large flowers, many open at a time, and creates a sensation whereever shown. (L. 12c ea.) (M. 8c ea.) (S. 5c ea.) (Blts. 35 c per 100 , $\$ 2.50$ per 1000 .)

RITA BECK (Fischer)-Clear shell pink with scarlet line on lip. Six to eight large, well placed flowers open at a time. Spike not clumsy but of good substance and stands up well. A good propagator and one that I believe has a bright future ahead. (S. \$1.25 ea.) (Blts. 25c ea.) 
RUTH TAYLOR (Diener)-Snow white, no markings, violet stamens. Very large blooms on tall strong spikes. (M. $\$ 1.50$ ea.)

ROZAN (Britsch)-That wonderful new pink put out by Wales Road Gardens. Of course you will want this one. (L. $\$ 15.00$ ea.) (M. $\$ 10.00$ ea.) (Blts. 50c ea.)

ROSE MIST (Fischer)-Old rose and buff. An extra good primulinus, admired by all who see it. (L. 60c ea.) (M. 40c ea.) (S. 25c ea.) (Blts. 60c per doz.)

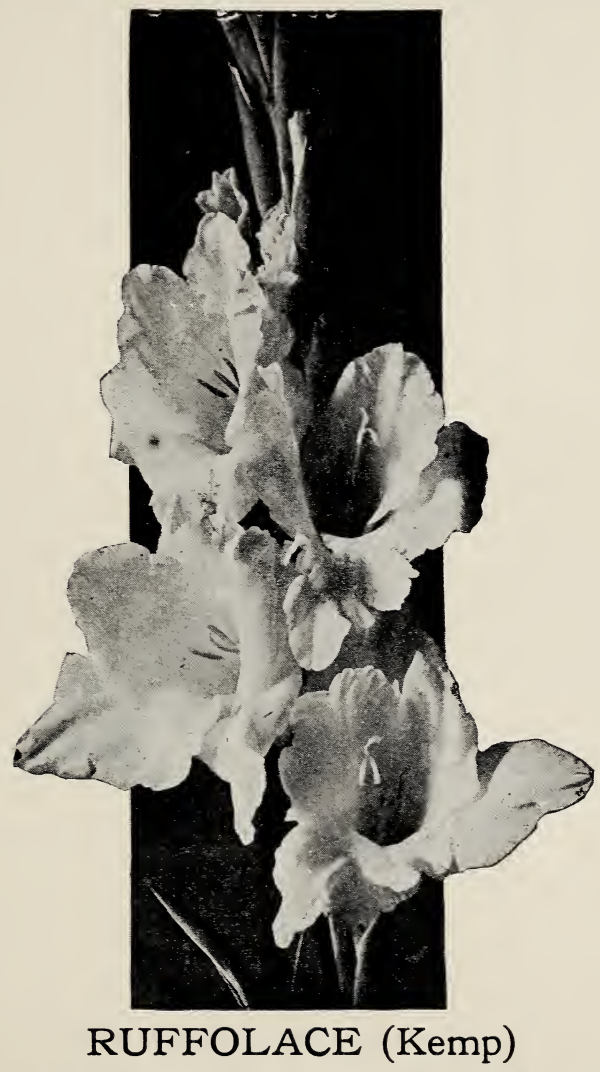

RUFFOLACE (Kemp)-A pure white ruffled and lacinated. Large bloom, vigorous grower, and a really worth while glad worthy of any high class collection. (L. $\$ 3.00$ ea.) (M. $\$ 2.00$ ea.) (S. $\$ 1.00$ ea.) (Blts. $30 \mathrm{c}$ ea.) 
ROSE ASH (Diener)-A pastel shade, ashes of roses. Strong tall grower, late bloomer and very pretty. (L. 6c ea., $\$ 4.50$ per 100.) (M. 3c ea., $\$ 2.25$ per 100.) (S. 2c ea., $\$ 1.00$ per 100.) (Blts. $10 \mathrm{c}$ per $100,75 \mathrm{c}$ per 1000.)

ROSEMARY (Bales)-Very unusual in coloring. White marked with fine hair lines and stripplings of lavender rose, which become pure pink under artificial light. Marking is carried clear through the petals so that the back of blossom looks the same as front. (L. 40c ea.) (M. 30c ea.) (S. 20c ea.) (Blts. 40c per doz.)

ROSE MULBERRY (Austin)-Coral pink flushed ageratum violet only approaches the beautiful coloring in this new one. Flowers have a tendency to face all around stem which adds to its effectiveness as a basket glad. Large blooms and very decorative. (L. $\$ 1.00$ ea.) (M. 50c ea.) (S. 25c ea.) (Blts. $\$ 1.00$ per doz.)

SACAJAWEA (Pratt)-Velvety red with golden bronze overcast. A new shade in the gladiolus field. (L. $\$ 3.25$ ea.) (M. \$2.25 ea.) (Blts. 35c ea.)

SANTA BARBARA (Briggs)-Large ruffled, delicate pink. Ruffles extending down entire petal. Six or more open at a time. Very pretty. (S. \$4.00 ea.)

SCARLET PRINCEPS (Kunderd)-An excellent scarlet rose. Large blooms ard many open at a time. (L. 6c ea.) (M. 4c ea.) (S. 3c ea.) (Blts. 15c per 100, $\$ 1.25$ per 1000 .)

SCARLET WONDER (Groff)-Enormous scarlet. Very prolific. You will want this one if you see it in bloom. (L. 15c ea.) (M. 10c ea.) (S. 5c ea.) (Blts. 25c per 100.)

SMOKY ROSE (Miller)-Very large lilac and old rose with a grayish sheen. Edges of petals slightly flecked slate blue. Narrow purple rose tongue. (L. \$3.00 ea.) (M. $\$ 2.00$ ea.) (S. $\$ 1.00$ ea.) (Blts. 30c ea.)

SONNENBERG (Bill)-Massive spikes of creamy pink, lightly flaked lavender pink. A dandy exhibition variety. (L. \$3.50 ea.) (M. \$2.25 ea.) (S. \$1.25 ea.) (Blts. 35c ea.)

SOUBOUTAI (Vilmorin)-Clear copper red, suffused with blue. Large white blotch. Good spike, large blooms and many open at a time. (L. 35c ea.) (Blts. 35c per doz.)

STARBRIGHT (Bales)-Daffodil yellow blooms with a broad and distinct stripe of rose through the center of each one of the six petals. Very unusual. (M. \$1.00 ea.) (S. $50 \mathrm{c}$ ea.) (Blts. $15 \mathrm{c}$ ea.) 
STAR OF THE SEA (Ellis)-(M. \$5.00 ea.) (S. $\$ 3.00$ ea.) (Blts. $50 \mathrm{c}$ ea.)

SUNSET GLOW (Gibbs)-A clear scarlet blended to a throat of purest golden yellow. (L. 10c ea., $\$ 7.00$ per 100.) (M. 7c ea., $\$ 5.00$ per 100.) (S. 4c ea., $\$ 3.00$ per 100.) (Blts. $20 \mathrm{c}$ per $100, \$ 1.50$ per 1000 .)

SWORD OF MAHOMET (Ellis)-(L. \$3.75 ea.) (S. \$1.75 ea.) (Blts. 20c ea.)

THE ARISTOCRAT (Bill)-Large slightly ruffled flower of pale saffron pink, flaked deep orange with cream throat and distinct violet feather. Strong grower and very pretty. (L. 90c ea.) (M. 65c ea.) (S. 35̃c ea.) (Blts. 90c per doz.)

THEDA (Bill)-Very early large flowers of shrimp pink, gradually blending to soft pinard yellow in the throat. Pansy violet lines on lower petals. (L. 20c ea.) (II. $15 \mathrm{c}$ ea.) (S. 7c ea.) (Blts. 10c per doz., 60c per 100.)

THE FLIRT (Austin)-A hybrid primulinus in a pleasing shade of garnet red with buds and back of bloom shaded to dark maroon. Medium size bloom. (L. 50c ea.) (M. 35c ea.) (S. 20c ea.) (Blts. 50c per doz.)

THE ORCHID (Sprague)--In color and shape a cattaleya orchid. One of the most beautiful glads I have seen. Flowers are too delicate to stand the hot sun here, but if cut and allowed to open in a cool place are beautiful beyond description. (L. \$2.50 ea.) (M. $\$ 1.80$ ea.) (S. $\$ 1.50$ ea.) (Blts. $30 \mathrm{c}$ ea.)

THE SWAN (Miller)-Very large round flower, tall spike, perfect placement. Heavy wax-like texture. In color snow white. (M. $\$ 5.00$ ea.) (S. $\$ 2.00$ ea.) (Blts. $75 \mathrm{c}$ ea.)

TIFFANY (Brown)-White. Heavy stock. Blooms of good substance. (L. 8c ea.) (M. 6c ea.) (S. 4c ea.) (Blts. 15c per $100, \$ 1.00$ per 1000.)

TRIUMPH (Pfitzer) - A gigantic new red that is creating a big stir among glad fans. (M. \$2.00 ea.) (S. \$1.00 ea.) (Blts. 30c ea.)

TYCốKO ZANG (Austin)-A beautiful shade of clear salmon pink with a brilliance unsurpassed under artificial light. Throat is white faintly dotted with deep cerise. Very large spike and foliage as well as bloom. Excellent propagator. (L. 40c ea.) (M. 25c ea.) (S. 15c ea.) (Blts. $\$ 1.00$ per $100, \$ 9.00$ per 1000.)

UNDINE (Thomas)-A strong grower, possessing that rare and beautiful color, pale amaranth pink. Lower petals slightly blotched with pale yellow. A good late cut flower variety. (L. 50c ea.) (M. 35c ea.) (S. 25c ea.) (Blts. 50c per doz.) 
VEILCHENBLAU (Pfitzer)-Violet-blue and a good one. (M. $\$ 1.25$ ea.) (S. $75 \mathrm{c}$ ea.) (Blts. $25 \mathrm{c}$ ea.)

VEILED BRILLIANCE (Austin)-Bright pink blooms with creamy throat, tinted grayish blue, having the apparance of being thinly veiled. Double row of large well placed flowers, with ten or more open at orce. Good propagator. (L. $\$ 2.75$ ea.) (M. $\$ 1.75$ ea.) (S. $\$ 1.25$ ea.) (Blts. 35c ea.)

VELVET BRONZE (Grossman)-Velvety nopal red, shaded garnet brown, bases of lower petals scarlet overlaid and blended deep nopal red, with bronze sheen over all. (M. $75 \mathrm{c}$ ea.) (S. 50c ea.) (Blts. $\$ 1.00$ per doz.)

VERMILLION ROSE (Miller)-Tall spike, large wide open round flowers. Six to eight open at once. Beautiful vermillion rose, throat lightly dusted white. Very prolific. (L. $\$ 3.00$ ea.) (M. $\$ 2.00$ ea.) (S. $\$ 1.00$ ea.) (Blts. 30c ea.)

WHITE GLORY (Kunderd)-Large intensely ruffled white, with blue lines. (L. 10c ea.) (M. 8c ea.) (S. 5c ea.) (Blts. 15c per 100.)

WHITE ORCHID (Bill)_The name best describes this beautiful glad. Large flowers of good substance. (L. $\$ 10.00$ ea.) (MI. $\$ 7.50$ ea.) (S. $\$ 5.00$ ea.) (Blts. $\$ 1.00$ ea.)

WHITE PREMIER (Bill)-A good new white, no markings, strong constitution and large bloom. (L. \$1.50 ea.) (II. $\$ 1.00$ ea.) (S. $75 \mathrm{c}$ ea.) (Blts. 15c ea.)

WHITE WONDER (Kemp)-Large white, good flower and spike. very prolific and the bulblets are easily germinated. (L. 6c ea., $\$ 4.50$ per 100.) (M. 4c. ea., $\$ 3.00$ per 100 .) (S. 2c ea., $\$ 1.25$ per 100.) (Blts. 10c per $100,75 \mathrm{c}$ per 1000 .)

WM. G. BADGER (Metzner)-A beautiful flower of delicate coral, edged deeper coral; throat pale yellow flaked with dark coral on lower petals. Flowers very large, many open at a time, good placement and on long spikes. (L. 20c ea.) (M. 12c ea.) (S. 7c ea.) (Blts. $45 \mathrm{c}$ per $100, \$ 4.00$ per 1000 .)

WM. KENT (Diener)-Ivory yellow suffused with rose pink at edges, throat buff yellow primrose, flaked carmine. Well ruffled and many open at a time. (L. $55 \mathrm{c}$ еа.) (M. 35c еа.) (S. 25c ea.) (Blts 35c per doz., $\$ 2.40$ per 100.)

YELLOW WONDER (Kunderd)-Tall vigorous plant and a very rapid multiplier. Flowers large, several open at a time. Almost buttercup yellow, slightly deeper in throat, without markings. (L. $\$ 3.00$ ea.) (M. \$1.50 ea.) (S. $75 \mathrm{c}$ ea.) (Blts. $15 \mathrm{c}$ ea., $\$ 10.00$ per 100.) 
YOUELL'S FAVORITE (Kunderd)-Ruffled rosy lavender pink. Conspicious and very fine. (L. 8c ea.) (M. $5 c$ ea.) (S. 3c ea.) (Blts. 15c per $100, \$ 1.00$ per 1000. )

\section{MIXED GLADIOLUS}

We do not advise buying mixed stock, however it is impossible to prevent leaving a few in the field when digging, so we put these in bins as mixed; then if customers wish a really good mixture we use about 1-4 of these and pick the rest out of our regular named varieties, insuring a wide range of colors in each dozen. These we sell as follows: (L. 75c per doz., $\$ 4.50$ per 100) (M. 50c per doz., $\$ 3.00$ per 100.) (S. 25c per doz., $\$ 1.50$ per 100 .)

\section{JUST A FEW TESTIMONIALS TO LET YOU KNOW WHAT MY CUSTOMERS THINK OF MY STOCK}

April 18, 1927.

Dear Mr. Melick: Your shipment of bulbs is at hand, and I wish to thank you sincerely for your liberal extras.

J. C. BIDDLE, Canada.

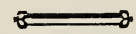

April 15, 1927.

Dear Sir: The bulblets which I ordered from you on March 26th came in on the 31st and I wish to thank you for your very prompt shipment of same, also for the extras you put in, both the extra count on those ordered and for the two "Break O' Day."

CHAS. F. COOMBS, Penna.

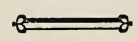

August 24, 1927.

Greetirgs, King: People drew by and then came back to get out and look at our glads. Don't know whether it's because of your stuff or my hoeing, it sure 'ain't' the ground, for I put them out in the mud last May. Say young feller, I will want some more for next year.

W. W. HARSHMAN, Ind.

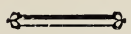

Oct. 26, 1927.

Dear Sir: I sent you an order for glad bulbs in the spring too late to be filled. Could you send me a list this fall and I will buy now? I had good luck with your bulbs a year ago, ard wish to buy from you now.

H. H. LEWIS, N. Y. 
April 21, 1927

Dear Sir: The cormels of the gladiolus "The Orchid," received. I thank you for sending the extra count. I am also grateful to you for sending the cormels of A. E. Kunderd. Again thanking you for your generous treatment, I am, Very truly yours,

N. VAN DECAR, N. Y.

All glad lovers should join the AMERICAN GLADIOLUS SOCIETY. The cost is only $\$ 2.00$ per year, which includes The Official Bulletin, a monthly magazine devoted exclusively to the gladiolus. Mail subscriptions to $\mathrm{Mr}$. ROSCOE HUFF, Goshen, Ind., or include $\$ 2.00$ with your order and I will see that you are enrolled as a member.

For general flower growing no magazine I have so far seen compares with THE FLOWER GROWER in dealing with all types of outdoor and indoor flowers. It is published by Madison Cooper at Calcium, N. Y. The price is $\$ 2.00$ per year, and I would be pleased to send in your subscription.

If you prefer either or both of the above instead of extras as listed in front of catalog, well and good. You may select either one instead of extras on a $\$ 25.00$ order or both on a $\$ 40.00$ order.

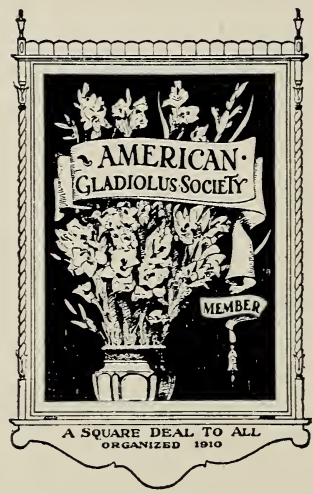



